\title{
NEPENTHES IZUMIAE (NEPENTHACEAE): A NEW SPECIES FROM SUMATRA
}

\author{
CHARLES CLARKE ${ }^{1,3}$, TROY DAVIS ${ }^{\mathrm{c} / 01} \&$ RUSJDI TAMIN ${ }^{2}$
}

\begin{abstract}
SUMMARY
Nepenthes izumiae Troy Davis, C. Clarke \& Tamin (Nepenthaceae), a new species from the Bukit Barisan, West Sumatra, Indonesia, is described.
\end{abstract}

Key words: Nepenthes izumiae, Bukit Barisan, Sumatra.

Recent explorations of the Barisan Range in Sumatra Barat have revealed the existence of at least two new taxa of Nepenthes (Clarke, 2001). One of these is described here as Nepenthes izumiae Troy Davis, C. Clarke \& Tamin. This taxon was briefly discussed and illustrated as 'Nepenthes species B' by Clarke (2001).

Nepenthes izumiae is characterised by its slender, cylindrical lower pitchers $(\leq 35$ $\mathrm{cm}$ in height), the outer surfaces of which are almost always heavily suffused with a dark purple pigment that makes them appear black in colour. The upper pitchers are also cylindrical, the outer surfaces being brownish purple. Both pitcher types possess a large, hook-shaped appendage on the lower surface of the pitcher lid.

Nepenthes izumiae appears to be closely related to $N$. singalana Becc., another montane species which is common in West Sumatra and Jambi. However, it differs from this species in a number of characteristics. The most obvious of these is the hookshaped appendage on the lower surface of the pitcher lid in N.izumiae, which is absent in N. singalana. However, it is found (in a less developed form) in pitchers of N. ovata Nerz \& Wistuba and (occasionally) in pitchers of $N$. bongso Korth., both of which also occur in montane habitats in Sumatra. The latter species produces infundibular aerial pitchers (Jebb \& Cheek, 1997), whereas those of N. izumiae are cylindrical throughout. Nepenthes izumiae also differs from $N$. singalana in that a number of simple, short, red-brown hairs are retained along the margins of the leaf blade, while the blades themselves are larger and broader. Table 1 outlines the principal differences between $N$. izumiae, $N$. singalana, $N$. bongso and $N$. ovata. Undoubtedly, $N$. singalana and $N$. izumiae are closely related, but the differences between them are both marked and stable. Accordingly, we feel that $N$. izumiae warrants distinction from $N$. singalana at specific rank.

1) Department of Biology, Hong Kong University of Science \& Technology, Clear Water Bay Road, Kowloon, Hong Kong.

2) University of Andalas, Andalas, Sumatera Barat, Indonesia.

3) Corresponding author [e-mail: boclarke@ust.hk]. 
Table 1. Distinguishing characteristics among N. izumiae, N. singalana, N. bongso and N. ovata.

\begin{tabular}{|c|c|c|c|c|}
\hline characteristic & N. izumiae & N. singalana & N. bongso & N. ovata \\
\hline $\begin{array}{l}\text { appendage under } \\
\text { lid }\end{array}$ & $\begin{array}{l}\text { present, very } \\
\text { large and hook- } \\
\text { shaped in mature } \\
\text { plants }\end{array}$ & absent & $\begin{array}{l}\text { usually absent, } \\
\text { but if present, } \\
\text { then not large } \\
\text { and hook shaped }\end{array}$ & $\begin{array}{l}\text { usually present, } \\
\text { often hook-shaped, } \\
\text { but never as well- } \\
\text { developed as in } \\
\text { N. izumiae }\end{array}$ \\
\hline $\begin{array}{l}\text { upper pitcher } \\
\text { shape }\end{array}$ & $\begin{array}{l}\text { cylindrical } \\
\text { throughout }\end{array}$ & $\begin{array}{l}\text { cylindrical } \\
\text { throughout }\end{array}$ & $\begin{array}{l}\text { infundibular } \\
\text { throughout }\end{array}$ & $\begin{array}{l}\text { infundibular } \\
\text { throughout }\end{array}$ \\
\hline $\begin{array}{l}\text { lower pitcher } \\
\text { shape }\end{array}$ & $\begin{array}{l}\text { infundibular at } \\
\text { the base, narrowly } \\
\text { ovoid in the next } \\
\text { third, then cylin- } \\
\text { drical above }\end{array}$ & $\begin{array}{l}\text { cylindrical } \\
\text { throughout }\end{array}$ & $\begin{array}{l}\text { cylindrical to } \\
\text { ovoid throughout }\end{array}$ & $\begin{array}{l}\text { ovoid to infundi- } \\
\text { bular throughout }\end{array}$ \\
\hline tendril insertion & $\begin{array}{l}\text { apical or } \\
\text { sub-peltate }\end{array}$ & apical & sub-peltate & apical \\
\hline leaf shape & broad, spathulate & $\begin{array}{l}\text { narrow, linear- } \\
\text { lanceolate }\end{array}$ & broad, spathulate & broad, spathulate \\
\hline $\begin{array}{l}\text { simple, red, short } \\
\text { hairs on margins } \\
\text { of blade }\end{array}$ & $\begin{array}{l}\text { mainly caducous, } \\
\text { but some persis- } \\
\text { tent }\end{array}$ & always absent & always absent & always absent \\
\hline $\begin{array}{l}\text { purple/black } \\
\text { pitcher pigment }\end{array}$ & always present & $\begin{array}{l}\text { nearly always } \\
\text { absent }\end{array}$ & always absent & always absent \\
\hline growth habit & epiphytic & $\begin{array}{l}\text { generally } \\
\text { terrestrial }\end{array}$ & $\begin{array}{l}\text { generally } \\
\text { epiphytic }\end{array}$ & $\begin{array}{l}\text { epiphytic or } \\
\text { terrestrial }\end{array}$ \\
\hline
\end{tabular}

As this taxon is large in stature, the holotype (Clarke, Davis \& Tamin 1309, ANDA) consists of four sheets. Sheet 1 comprises an immature rosette bearing lower pitchers, Sheet 2 comprises a fragment of a climbing stem bearing an upper pitcher, while Sheets 3 and 4 each contain a single large lower pitcher. The material on each sheet was collected from different plants, but all belonged to the same population, were found within 30 metres of each other and are representative of N. izumiae. The only other Nepenthes species present at the collection site (N.jacquelineae C. Clarke, Troy Davis \& Tamin) cannot be confused with the present species.

\section{Nepenthes izumiae Troy Davis, C. Clarke \& Tamin, spec.nov.}

Nepenthi singalanae similis, sed appendice grandi unciformi in superficie, inferiore operculi ascidii, indumento persistenti in marginibus lamina atque foliis maioribus latioribus differt. - Holotypus: Clarke, Davis \& Tamin 1309 (ANDA), Indonesia, Sumatera Barat, Bukit Barisan, north of Bukittinggi, 13 July 2000.

Climber to $5 \mathrm{~m}$. Stem cylindrical to angular, $\leq 0.8 \mathrm{~cm}$ in diameter, internodes $\leq 12 \mathrm{~cm}$ long on climbing stems, $\leq 1.0 \mathrm{~cm}$ on rosettes. Leaf blades of the rosettes and short shoots coriaceous, broadly lanceolate to spathulate, $\leq 25 \mathrm{~cm}$ long, $\leq 8 \mathrm{~cm}$ wide, ses- 
sile. Longitudinal veins 3 on each side of the midrib, pennate veins arising obliquely from the midrib, but difficult to distinguish. Leaf blade narrowed towards the base, but widening again at the point where it is attached to the stem, clasping the stem for $1 / 2$ of its circumference. Tendrils $\leq 30 \mathrm{~cm}$ long, straight, very robust on rosettes produced by mature plants. Leaves of the climbing stems coriaceous, $\leq 20 \mathrm{~cm}$ long, $\leq 3 \mathrm{~cm}$ wide, ovate, apex rounded. Leaf blade narrows slightly towards the base, not becoming wider again at the point of attachment to the stem. Base clasps the stem for approximately $1 / 2$ of its circumference. Tendrils $\leq 25 \mathrm{~cm}$ long, less robust than those of rosettes, usually with a loop in the middle. On large lower pitchers, the insertion of the tendril is usually be sub-apical by 1-2 $\mathrm{mm}$, in which case the apex of the leaf blade is elongated and obtuse. Pitchers of the rosettes arising gradually from the end of the tendril, $\leq 30 \mathrm{~cm}$ high, $\leq 6 \mathrm{~cm}$ wide. Lower $1 / 4$ infundibular, next $1 / 4$ narrowly ovoid, upper $1 / 2$ cylindrical and contacted above the ovoid part but lacking a distinct hip. Cylindrical upper portion widens slightly just below the mouth. Two wings $(\leq 6$ $\mathrm{mm}$ wide), bearing multi-cellular fringe elements ( $\leq 9 \mathrm{~mm}$ long) run from the top to the bottom of the pitcher at the front. Glandular region on the inner surface extends from the bottom of the pitcher to the top of the ovoid portion, digestive glands barely hooded, not significantly raised above the glandular surface of the pitcher wall, $\leq 150 \mathrm{~cm}^{2}$. Mouth of pitchers round, $\leq 6 \mathrm{~cm}$ in diameter, steeply oblique, almost vertical at the rear. Peristome $\leq 3 \mathrm{~cm}$ wide, widest just below the lid, narrowest at the front. Inner margin bearing pronounced, narrow teeth, $\leq 1 \mathrm{~cm}$ long. Ribs $\leq 4 \mathrm{~mm}$ apart, raised to $3 \mathrm{~mm}$. Lid orbicular, very strongly cordate at the base, $\leq 8 \mathrm{~cm}$ in diameter, with a pronounced, hook-shaped appendage ( $\leq 1 \mathrm{~cm}$ long) on the lower surface, towards the base. Large nectar glands, $\leq 1 \mathrm{~mm}$ across occur on the spur and midline of the lower surface of the lid. The rest of the underside of the lid is virtually devoid of nectar glands. Spur simple, $\leq 1 \mathrm{~cm}$ long. Upper pitchers rarely produced, arising gradually from the tendril, widening very little throughout the curl, infundibular in the lower $1 / 3$, contracted to a distinct hip, then cylindrical above; not widening towards the mouth; $\leq 15 \mathrm{~cm}$ high, $\leq 4 \mathrm{~cm}$ wide. Mouth round, oblique, elongated into a short neck at the apex. Peristome narrow and generally cylindrical (sometimes expanded slightly at the sides) $\leq 8 \mathrm{~mm}$ wide, ribs distinct, raised $0.5 \mathrm{~mm}$, teeth distinct, $\leq 1.5 \mathrm{~mm}$ long. Glandular region on inner surface covers the lower portion below the hip. Wings reduced to ribs, multicellular fringe hairs absent. Lid sub-orbicular, $\leq 4 \mathrm{~cm}$ wide, same size as the pitcher mouth, cordate at the base, structure of glandular crest and distribution nectar glands the same as in the lower pitchers. Spur short and simple, $\leq 0.5 \mathrm{~cm}$ long. Female inflorescence a raceme, peduncle $\leq 10 \mathrm{~cm}$, rachis $\leq 8 \mathrm{~cm}$. Pedicels $\leq 1 \mathrm{~cm}$ long, bracts and bracteoles absent, sepals ovate, $\leq 6 \mathrm{~mm}$ long. Mature capsules $\leq 1.5 \mathrm{~cm}$ long. Male inflorescence unknown. Indumentum on immature tendrils comprised of soft, white and red-brown hairs, most which are caducous. Rosette leaves glabrous above and below, margins lined with simple, short, white hairs, about $50 \%$ of which are persistent. Leaves of climbing stem very sparsely covered with simple, short, white hairs on the upper surface; lower surface glabrous. Margins densely covered with short, simple, brown hairs when young; many of these are caducous, but some are retained towards the apex. Leaf axils covered with short, stellate, light brown hairs. Outer surfaces of lower pitchers and upper surface of lid densely covered with red-brown stellate hairs; spur sparsely covered with downy, red, simple hairs. Mature tendrils sparsely covered with very short, simple, 
white hairs. Outer surface of upper pitchers and upper surface of lid densely covered with very short, white, stellate hairs. Peduncle, rachis, pedicels and capsules of female inflorescence densely covered with short, brown, stellate hairs.

Distribution - Sumatra (Sumatra Barat, Bukit Barisan).

Habitat - At the type locality, growing strictly as an epiphyte in upper montane forest above $1700 \mathrm{~m}$ above sea level.

Etymology - Named in honour of Izumi Davis, wife of T. Davis.

Specimens examined include:

Nepenthes izumiae - Clarke, Davis \& Tamin 1309 (holo ANDA).

Nepenthes singalana - Beccari 187 (isolecto K); Bünnemeijer 2692, 2693, 4028, 9997 (BO); Des \&

Tamin 529 (ANDA); Frey-Wyssling 107 (BO); Meijer 3590, 5841 (BO).

Nepenthes ovata - Frey-Wyssling 13, 43 (BO); Nerz 1601 (holo L); Opperhout 21/11/1929 (BO).

Nepenthes bongso - Bünnemeijer 4230, 5521 (BO); Des \& Tamin 523 (ANDA); Hotta \& Tamin 40

(ANDA); Korthals s.n. (L); Meijer 6142 (BO); Nerz 2401 (L); Tamin 2326 (ANDA).

\section{ACKNOWLEDGEMENTS}

The authors are grateful for the support and assistance of Dr. Irawati at Herbarium Bogoriense, Pak Budiman and his wife, Rosiana, and the staff of the Herbarium at the University of Andalas. We thank Dr. Alan Radcliffe-Smith of the Royal Botanic Gardens, Kew, for providing the Latin diagnosis.

\section{REFERENCES}

Clarke, C.M. 2001. Nepenthes of Sumatra \& Peninsular Malaysia. Natural History Publications (Borneo), Kota Kinabalu, Sabah.

Jebb, M.H.P. \& M. Cheek. 1997. A skeletal revision of Nepenthes (Nepenthaceae). Blumea 41: $1-106$. 